\title{
Article
}

\section{Fineness of Coal Fly Ash for Use in Cement and Concrete}

\author{
Miguel Ángel Sanjuán 1,*(D) and Cristina Argiz 2 (D) \\ 1 Spanish Institute of Cement and Its Applications (IECA), C/José Abascal, 53, 28003 Madrid, Spain \\ 2 Civil Engineering School, Technical University of Madrid, C/Profesor Aranguren, 3, Ciudad Universitaria, \\ 28040 Madrid, Spain; cg.argiz@upm.es \\ * Correspondence: masanjuan@ieca.es; Tel.: +34-914-429-166
}

check for

updates

Citation: Sanjuán, M.Á.; Argiz, C. Fineness of Coal Fly Ash for Use in Cement and Concrete. Fuels 2021, 2, 471-486. https://doi.org/ $10.3390 /$ fuels 2040027

Academic Editor: Manoj Khandelwal

Received: 6 November 2021

Accepted: 22 November 2021

Published: 25 November 2021

Publisher's Note: MDPI stays neutral with regard to jurisdictional claims in published maps and institutional affiliations.

Copyright: (c) 2021 by the authors. Licensee MDPI, Basel, Switzerland. This article is an open access article distributed under the terms and conditions of the Creative Commons Attribution (CC BY) license (https:// creativecommons.org/licenses/by/ $4.0 /)$.

\begin{abstract}
Nowadays, coal is increasingly being used as an energy source in some countries. This coal-fired generation process, however, has the disadvantage that produces large quantities of coal fly ash. Its characteristics differ depending on the combustion conditions and the coal source. Fineness will influence early compressive strength in cement-based materials. The finer the binding material, the higher the early compressive strength. They can be used to produce high-volume fly ash (HVFA) concrete, self-compacting concrete (SCC), concrete for marine infrastructures, pervious concrete, roller compacted concrete (RCC) and so on.More than seven hundred samples of coal fly ash were collected from a coal-fired power plant for a period of ten years, and their fineness were characterized by sieving. The average fineness on $45 \mu \mathrm{m}, 63 \mu \mathrm{m}, 90 \mu \mathrm{m}$ and $200 \mu \mathrm{m}$ mesh sieves were $22.5 \%, 15.5 \%$, $9.1 \%$ and $2.0 \%$, respectively. Then, most of the coal fly ash particles were lower than $45 \mu \mathrm{m}$, i.e., from 15 to $30 \%$ were retained on the $45 \mu \mathrm{m}$ sieve, and from 10 to $20 \%$ by mass of coal fly ash particles were retained on a $63 \mu \mathrm{m}$ sieve. Fineness on a $45 \mu \mathrm{m}$ sieve is a good indirect indicator of the residues on the $63 \mu \mathrm{m}, 90 \mu \mathrm{m}$ and $200 \mu \mathrm{m}$ mesh sieves. Accordingly, it is suggested to broaden the range from $\pm 5 \%$ to as high as $\pm 7 \%$ regarding the fineness variation requirement. Finally, the tested coal fly ash can be applied as cement constituent.
\end{abstract}

Keywords: coal fly ash; fineness; grate furnace combustion; standardization

\section{Introduction}

Coal fly ash (CFA) is the major combustion residue produced during the burning of pulverized coal in thermo-electric power stations. About of $80-90 \%$ of the total ashes are collected by the cleaning equipment of flue emissions, usually are electrostatic precipitators. Spain utilizes imported bituminous coal from South Africa, among other countries, as fossil fuel, for electrical power generation [1].

Coal-fired power generation is not decreasing around the world. Therefore, the upsurge in the coal demand will also increase the production of coal fly ash. After three years of growth, it reached a record of over 10,000 TWh in 2018. Later, it dropped by 3\% in 2019. Even though coal-fired power generation decreased in Europe and the United States, it grew up in China and other parts of Asia, where it is the largest source of power generation (36\%). Currently, coal supplies 36.7\% (2019) of global electricity generation and plays a significant role in iron and steel industry. The share of global power mix in 2019 was slightly lower than in 1973 (38.2\%) [2]. In particular, Spain accounts for around 1.9\% of the worldwide global coal consumption of 1140 million tons, which is the 29th place. Annually, the Spanish utilities consume 22 million tons (2016) of coal, producing about 310,000 tons of coal bottom ash (CBA) and 2.2 Mt of coal fly ash (CFA) [1].

Recently, some countries currently using coal for electricity generation have agreed for a gradual reduction of its use. This action is aligned with the European milestone of becoming climate-neutral by 2050 . 
The European Green Deal is focused on climate change mitigation. Furthermore, it covers investment, research, innovation, growth, and related strategies such as climate change adaptation [3].

The target set out in the EU Green Deal for Europe's ambition to become climate neutral by 2050 was written into law in The European Climate Law [4]. In addition, an intermediate target of decreasing net greenhouse gas (GHG) emissions by at least $55 \%$ by 2030, compared to 1990 levels was established. This law implies a radical transformation of Europe's economy and society. Therefore, new initiatives, across economic sectors such as energy and fuels and a range of policy areas should be adopted. Finally, The European Circular Economy Action plan describes the actions dealing with resource extraction and waste among other topics [5]. In Europe, the construction sector is responsible for about $35 \%$ of the total waste generation. In addition, greenhouse gas (GHG) emissions from material extraction, construction product manufacturing and building construction and renovation are estimated in the range of $5-12 \%$ of the national greenhouse gas (GHG) emissions reported by the European countries.

The use of by-products and industrial wastes, such as coal fly ash, as supplementary cementitious materials to manufacture coal-ash cements and concretes is a lever to achieve net zero carbon dioxide emissions in the cement production [6]. Therefore, the cement and concrete sectors play a key role in circularity. The major advantages of using coal fly ash in cements and concretes are the mitigation of the climate change by lowering the clinker to cement ratio and the increase of the concrete durability, which increases the service life of reinforced concrete structures. In addition, carbon dioxide uptake by cement-based materials carbonation can be considered in the carbon dioxide net balance for the cement and cement-based materials, and it is widely acknowledged by scientists that coal-ash cements and concretes carbonate faster than the ones made with common cements without additions [6]. Summing up, coal fly ash added to Portland cements and concretes are an important lever for decarbonization.

The benefits of coal fly ash as a cement constituent derive from its pozzolanic performance. Coal fly ash reacts with calcium hydroxide from cement hydration reactions to form calcium silicate hydrates called C-S-H gel, contributing to the strength gain of the Portland cement [7]. Coal bottom ash also exhibits a pozzolanic reactivity in blended cements when it is finely ground [8]. However, it is normally used as fine aggregate [9], but sometimes is dumped in landfills. Coal fly ash in cements for structural concrete applications typically ranges from 6 to $20 \mathrm{wt} \%$, which are cements CEM II/A-V, and from 21 to $35 \mathrm{wt} \%$, which are cements CEM II/B-V, according to the European standard EN 197-1:2011 [10]. CEM IV / A (V) and CEM IV / B (V) cements could have a coal fly ash content up to $55 \mathrm{wt} \%$ and are used for mass concrete in roller compacted concrete pavements and dams, among other applications [11]. Although coal fly-ash typically enhances long term strength of concrete, it also tends to delay early strength development [12]. The European standard EN 450-1 [13] stipulates that the compressive strength of mortars containing $25 \%$ coal fly ash must be at least $75 \%$ that of coal ash-free mortar after 28 days of curing (activity index). Also, the activity index at 91 days has to be at least $85 \%$. Coal fly ash (CFA) from the combustion of bituminous coal from South Africa was found to meet these requirements at substitutions up to $35 \mathrm{wt} \%$ [14]. Also, it was found that its particle size distribution (PSD) can affect positively in the compressive strength development [15]. Long-term mechanical strength and long-lasting durability is improved with coal fly ash more rich in smaller particles [16]. Accordingly, the small hollow spheres with a size ranging from 10 to $1000 \mu \mathrm{m}$ in diameter, named cenospheres, are very wanted [17], which are the smaller particles (from 1 to $2 \%$ of the total) [18]. Most of them present diameters from 5 to $500 \mu \mathrm{m}$ [19] or from 20 to $300 \mu \mathrm{m}$. The shell thickness varies from 1 to $18 \mu \mathrm{m}$ [20]. Finally, its microstructure contains around $76 \%, 22 \%$ and $2 \%$ of glass, mineral matter or char, respectively [17].

To both achieve climate change mitigation targets and as well as for the use of coal fly ash, high-volume coal fly ash (HVFA) concrete has been developed in which more than $50 \%$ of coal fly ash is utilized in the binder mixture in concrete [21]. High-volume 
fly ash (HVFA) concrete, which has normally $50-60 \%$ coal fly ash as the total content of cementitious materials, is widely used.

Coal fly ash in concrete has several advantages, such as increasing the resistance to chloride penetration, sulphate attack, and alkali-silica reaction, lowering cracking due to drying and thermal shrinkage, improving the workability and reducing the water demand [22]. By contrast, most of the studies reported that coal fly ash provides early age compressive strength to the concrete [23,24], but at the later ages its contribution to compressive strength becomes larger. Furthermore, wet-curing periods result in lower compressive strength, and more porous and permeable concretes $[25,26]$.

High-volume coal fly ash concrete presents good mechanical strength utilizing 50-60\% of coal fly ash replacement. However, at replacement levels beyond this the mechanical strength decreases, particularly at early ages, due to the slow pozzolanic reaction [27-29]. It has been reported compressive strength of $66.55 \mathrm{MPa}$ [29] when $50 \%$ of cement was replaced (HVFA-50 concrete) at 28 days this value was reduced to $30.55 \mathrm{MPa}$ for HVFA-70 concrete. In addition, compressive strengths at 28 days equivalent to $78 \%$ and $73 \%$ of the reference compressive strength (concrete without coal fly ash) for HVFA-40 and HVFA-60 concretes, respectively, have been reported [27-30].

According to Ankur, et al. [31], the application of high-volume coal fly ash (HVFA) based self-compacting concrete (SCC) is feasible for civil engineering works where early mechanical strength is not the deciding design factor. In addition, coal fly ash levels higher than $30 \%$ normally hinders the compressive strength of the self-compacting concrete Therefore, the use of HVFA based SCC should not exceed $40-50 \%$ of coal fly ash percentage. By contrast, the use of coal fly ash in high volume in self-compacting concrete may contribute to promotion of SCC in developing countries.

Coal fly ash blended cements enhance the durability of concrete by its particle packing effects and pozzolanic reaction [32]. Nevertheless, its effectiveness level depends on the concrete mix design, curing conditions and type of coal fly ash. Accordingly, this material provides enhanced durability in the marine environment [33], i.e., a good resistance to chloride penetration into the concrete for marine infrastructure [34].

High strength concrete is widely utilized in civil engineering due to its better mechanical and durability characteristics than conventional concrete. Coal fly ash high strength concrete is more crack resistant due to the lower cement content and mixing water [35]. In addition, the uniaxial tensile strength of hardening coal fly ash high strength concrete at early age is generally lower than splitting tensile strength at the same age [36].

Pervious concrete, i.e., no-fines concrete, is a pavement concrete with high porosity and, therefore, high water permeability. Vázquez-Rivera et al. [37] reported compressive strength and density values of pervious concrete ranging from $2.5 \mathrm{MPa}$ to $13.5 \mathrm{MPa}$ and $2120-2360 \mathrm{~kg} / \mathrm{m}^{3}$, respectively, while the increase in coal fly ash/binder ratio results in the decrease of the concrete compressive strength. Coal fly ash in concrete (10-30\%) provides a more workable mix and a good abrasion resistance because of the pozzolanic reaction and filler effect. Nevertheless, compressive strength are about 0.85 times that of control mix [38]. Although, $20 \%$ coal fly ash decreases the porosity and increases the density, the compressive strength is lower compared to that of $10 \%$ coal fly ash [39]. Finally, it is suggested to utilize pervious concrete made with high levels of coal fly ash as base layer in rigid pavements. By contrast, Saboo et al. [40] suggest an optimum range of coal fly ash replacement in pervious concrete between 5 and $15 \%$.

The use of large amounts of coal fly ash in roller compacted concrete (RCC) reduces the hydration temperature and enhances durability [41]. Then, it is suitable for use in dams and pavements [42]. The increase in coal fly ash content in roller compacted concrete (RCC) adversely affects its compressive strength. In addition, the increase in coal fly ash replacement promotes the formation of interlayer cold joints [43]. Furthermore, with the increase of the delay of placement time of the roller compacted concrete (RCC) upper layer, it shows lower splitting-tensile strength and higher permeability [44]. 
Sahmaran et al. [45] studied the effect of self-healing on self-consolidating concrete made with high volume of coal fly ash (HVFA) when submitted to permanent water exposure. The self-healing effect was attributed to the pozzolanic reaction of un-hydrated coal fly ash particles available in the pore system, which hydrates on the crack surfaces filling the crack by newly formed C-S-H gels.

Jing et al. [46] reported the use of coal fly ash cenospheres to produce ultra highperformanceconcrete (UHPC). They show an improvement of the hydration process of ultra high-performance at early age and a filler effect at 28 days.

Ultrafine coal fly ash may refine the pore diameter and improve the workability of ultra high-performance concrete pastes compared with the ones containing high-volume of ordinary coal fly ash [47]. The high specific surface area and filler effect of fine coal fly ash leads to higher compressive strength $[47,48]$. However, workability is a key factor for the development of ultra-high mechanical properties and good durability of ultra high-performance concrete [49].

The objective of this research was to characterize the fineness of coal fly ash (CFA) samples generated from South African coal. All the samples of coal fly ash were obtained from the Carboneras thermoelectric power plant in Spain. Hence, coal fly ash fineness and particle size distribution were truly representative of most of the thermoelectric power plants with similar equipment configuration and combustion conditions.

\section{Research Motivation, Significance, and Limitations of the Results}

According to the IPCC the Sixth Assessment Report (AR6) Climate Change 2021 report entitled "The Physical Science Basis" [50], earth is warmer (about $1.1^{\circ} \mathrm{C}$ ) than it has been in 125 thousand years, but very negative consequences can be avoided by defining adequate building materials made with low embodied carbon.

Furthermore, achieving climate change mitigation goals within the construction sector has become a major aim as the demand for new buildings and civil infrastructures increase with rising the worldwide population. In addition, concrete is the most used construction material, in which common Portland cement is the main constituent and it is estimated that the current demand for world concrete is ranged between 1200 and 2700 million of cubic meters per annum.

The production of Portland cement clinker contributes towards some environmental negative impacts including energy and natural resources consumption, and carbon dioxide emission to the atmosphere, making up $7.4 \%$ of the worldwide anthropogenic carbon dioxide emission (2.9 Gtons in 2016) [51]. Accordingly, carbon dioxide emissions can be reduced by lowering the clinker factor to produce blended Portland cements by employing additions such as coal fly ash to replace the clinker in Portland cements [6]. Even though the annual global fly ash generation is more than one thousand million tons [2], utilization was only about $50 \%$ of the total coal ash generated [52]. As stated in the previous section, coal fly ash has been dumped in landfills, which has serious environmental, social, economic and population health consequences.

The incorporation of coal fly ash in concrete with a higher variation than the currently specified in the standards is a pioneer move that could transform the scenario of the cement and concrete sectors. The variation requirement specified by the ASTM C 618 is considered strict and unrealistic, which constitutes the most frequent reason of coal fly ash failing to meet requirements. Therefore, there is a clear gap in the understanding of using coal fly ash with a higher variation range than $\pm 5 \%$. As there are no long-term data available for coal fly ash fineness, this study will provide test results recorded for ten years to assess the fineness variation of coal fly ash to fill that gap.

This study assesses the viability to expand the variation range of suitable coal fly ash from $\pm 5 \%$ to a higher range. Additionally, a statistical analysis is conducted to predict the relationship between the coal fly ash retained in the $45 \mu \mathrm{m}$ mesh sieve and the rest of residues obtained on the $63 \mu \mathrm{m}, 90 \mu \mathrm{m}$ and $200 \mu \mathrm{m}$ sieves. Nevertheless, the limitations of this study may arise from the coal fly ash nature, which depends on the coal source. 


\section{Materials and Methods}

\subsection{Coal Fly Ash Sampling}

Coal fly ash samples supplied by the Carboneras coal-fired power station at Almería, Spain, were picked when the coal-fired power station was running at full load. They were picked at the point of release for ten years, then, a total of seven hundred sixty-five spot samples were characterized by sieving.

\subsection{Assessment of Coal Fly Ash Fineness}

In order to classify the coal fly ash, its fineness must be expressed as the mass proportion of the material retained, in percent, when it is sieved on a $45 \mu \mathrm{m}$ mesh sieve according to the European standard EN 450-1 [13]. Accordingly, the percentage must fall within the limits of the following categories: $\mathrm{N}$ (fineness cannot exceed $40 \%$ ), and $\mathrm{S}$ (cannot surpass $12 \%)$. This article presents the results obtained in coal fly ash spot samples, when they were sieved on four sieves: $45 \mu \mathrm{m}, 63 \mu \mathrm{m}, 90 \mu \mathrm{m}$ and $200 \mu \mathrm{m}$. The wet sieving method described in the European standard EN 451-2 was used to determine the fineness [53].

\subsection{Coal Fly Ash Characterization}

Table 1 shows the average chemical composition of the tested coal fly ash. An X-ray fluorescence (XRF) spectrometer Bruker S8 Tigger $4 \mathrm{~kW}$ model was used to determine the $\mathrm{SiO}_{2}, \mathrm{Al}_{2} \mathrm{O}_{3}, \mathrm{Fe}_{2} \mathrm{O}_{3}, \mathrm{CaO}, \mathrm{MgO}, \mathrm{SO}_{3}, \mathrm{~K}_{2} \mathrm{O}, \mathrm{Ti}_{2} \mathrm{O}_{5}$ and $\mathrm{P}_{2} \mathrm{O}_{5}$ content, whereas, insoluble residue, IR, loss on ignition, LOI, and chloride content were determined according to the European standard EN 196-2 [54]. Accordingly, the coal fly ash used in this study, which is typical product of a low-lime bituminous coal combustion, conform to European Standard EN 450-1 [13].

Table 1. Average chemical compositions of coal fly ash (\%).

\begin{tabular}{ccccccccccccc}
\hline Oxide & $\mathrm{SiO}_{2}$ & $\mathrm{Al}_{2} \mathbf{O}_{3}$ & $\mathrm{CaO}$ & $\mathrm{Fe}_{2} \mathbf{O}_{3}$ & $\mathbf{M g O}$ & $\mathrm{SO}_{3}$ & $\mathbf{K}_{2} \mathbf{O}$ & $\mathrm{Ti}_{2} \mathbf{O}_{5}$ & $\mathbf{P}_{2} \mathrm{O}_{5}$ & $\mathbf{L O I}$ & $\mathbf{I R}^{\mathbf{1}}$ & $\mathbf{C l}^{-}$ \\
\hline Content (\%) & 50.5 & 28.9 & 5.0 & 4.7 & 1.8 & 0.21 & 0.8 & 1.56 & 0.76 & 3.6 & 71.3 & 0.001 \\
\hline
\end{tabular}

${ }^{1}$ Insoluble residue determined by the $\mathrm{Na}_{2} \mathrm{CO}_{3}$ method (European standard EN 196-2).

Figure 1 shows the Scanning electron microscope image and particle size distribution (PSD) of coal fly ash. As it can be seen in the image, coal fly ash consists of fine particles predominantly spherical in shape, either solid or hollow, and mostly amorphous.

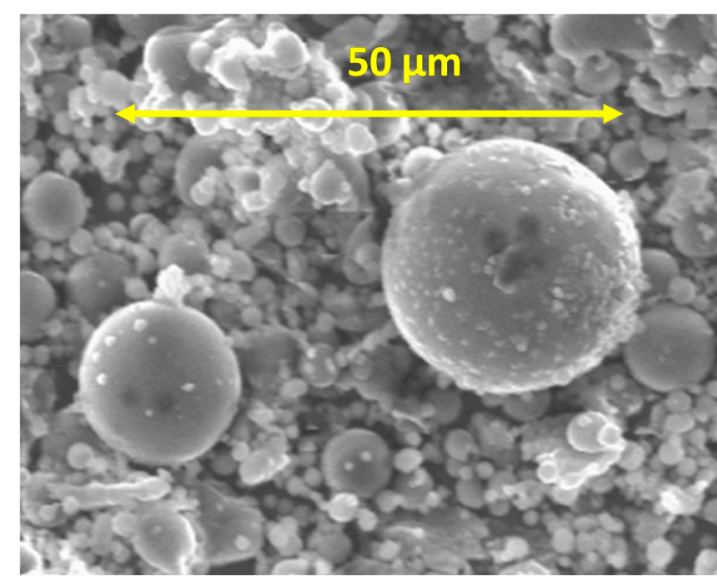

(a)

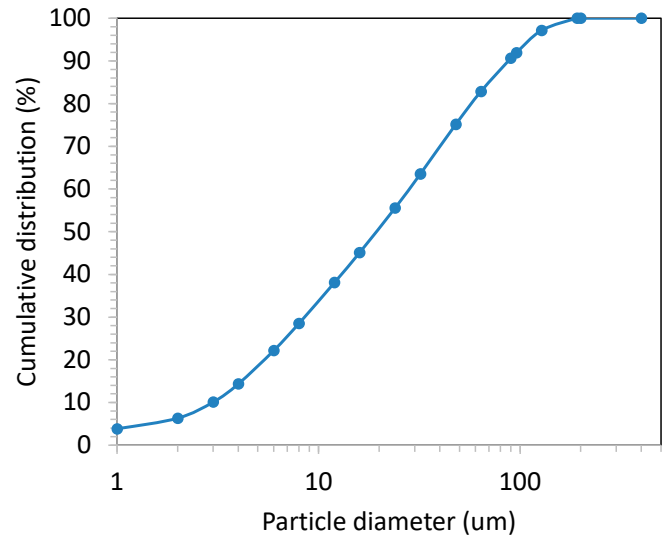

(b)

Figure 1. Coal fly ash: (a) Scanning electron microscope image; (b) particle size distribution (PSD). 


\section{Results}

\subsection{Residues on $45 \mu \mathrm{m}, 63 \mu \mathrm{m}, 90 \mu \mathrm{m}$ and $200 \mu \mathrm{m}$}

Figure 2 shows the results obtained in seven hundred sixty-five spot samples taken for ten years at the Carboneras coal-fired power station. They are the residues on $45 \mu \mathrm{m}$, $63 \mu \mathrm{m}, 90 \mu \mathrm{m}$ and $200 \mu \mathrm{m}$ mesh sieves. For the most part they fall below $45 \mu \mathrm{m}$, i.e., about $70 \%$, as shown in Figure 2a.

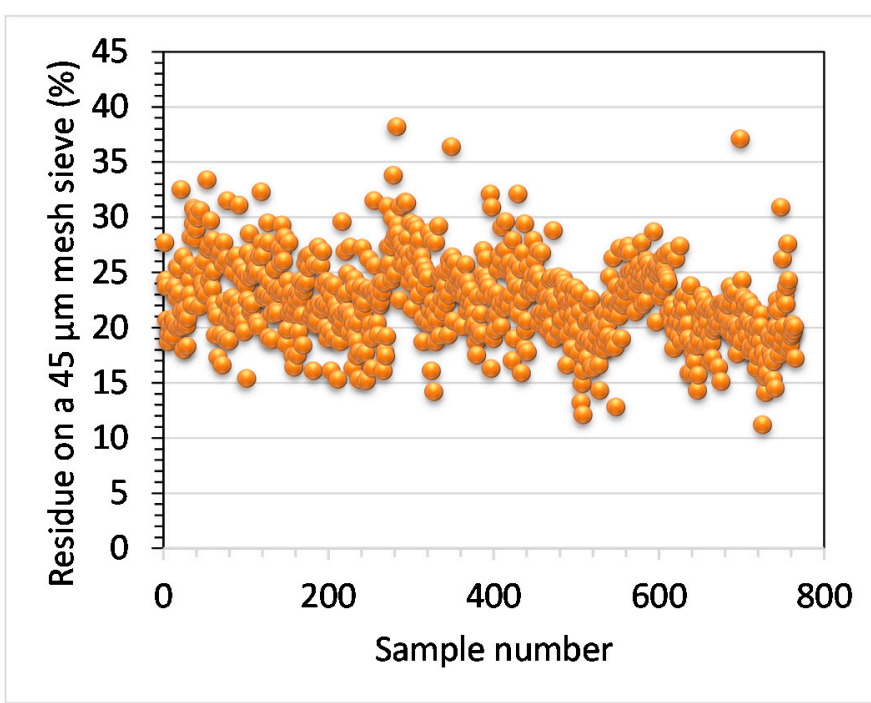

(a)

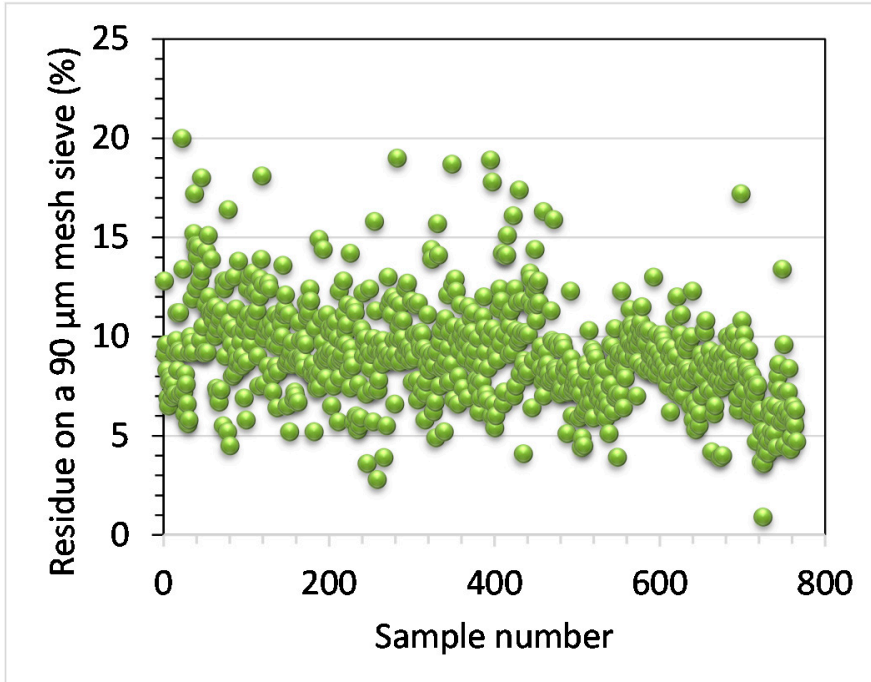

(c)

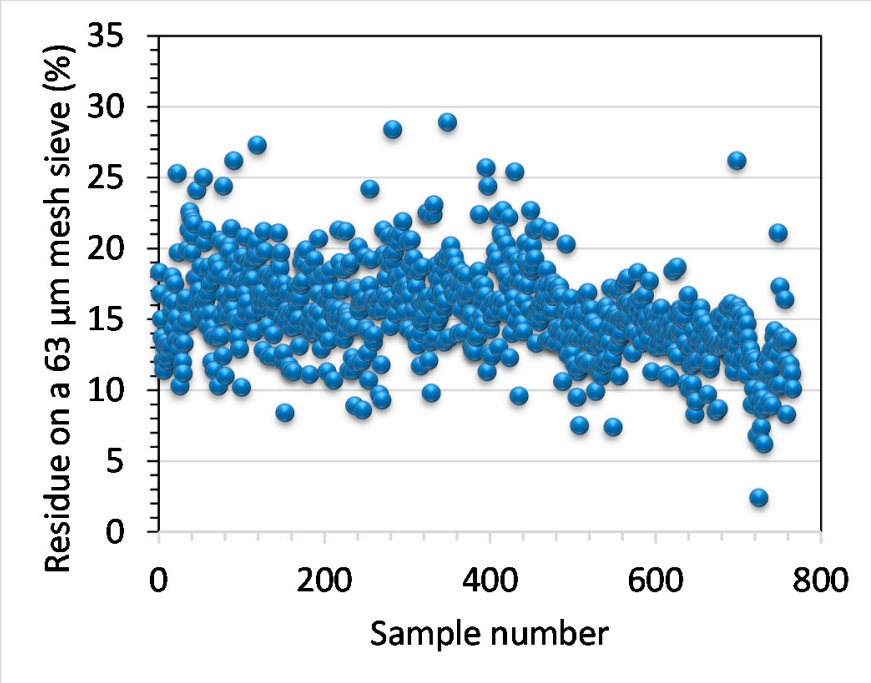

(b)

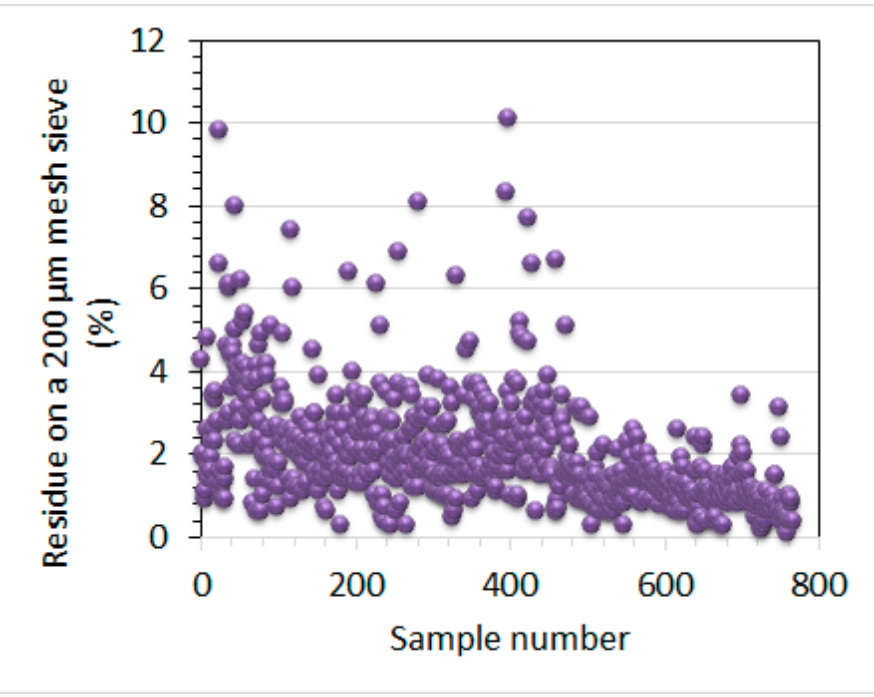

(d)

Figure 2. Residue of 765 samples, collected for ten years, on a $45 \mu \mathrm{m} ; 63 \mu \mathrm{m} ; 90 \mu \mathrm{m}$ and $200 \mu \mathrm{m}$ mesh sieve: (a) $45 \mu \mathrm{m}$; (b) $63 \mu \mathrm{m}$; (c) $90 \mu \mathrm{m}$; (d) $200 \mu \mathrm{m}$.

The standing European standard for coal fly ash, i.e., EN 450-1 [13] specifies a threshold value on the highest amount retained, which is a $40 \%$. In addition, the highest fineness variation of $\pm 10 \%$ from the average value of the last ten spot samples is specified. The mass retained on $45 \mu \mathrm{m}$ sieve was recorded and the percentage of retained material was calculated. As shown in Figure 2a, coal fly ash fineness varies from $11.2 \%$ to $38.2 \%$, retained by a sieve with apertures of $45 \mu \mathrm{m}$. Accordingly, the coal fly ash reported in this study comply with the requirements set out in EN 450-1 [13].

The considerable divergence of batches of coal employed as well as the difference of process conditions along the time were likewise criticized as contributing to the scatter in 
a data plot. Furthermore, the random testing error, amongst others unspecified sources of systematic error, can be important, and likely contributes to the scatter in the fineness determination. Presuming that the results follow a normal distribution pattern, upper, U, and lower, L, limits were calculated from the $\overline{\mathrm{Y}}$ the mean value, the standard deviation, $\mathrm{s}$, and the acceptability constant, $k_{a}$, according to Equations (1) and (2), respectively [13].

$$
\begin{aligned}
& \mathrm{U}=\overline{\mathrm{y}}+k_{a} \times \mathrm{s} \\
& \mathrm{L}=\overline{\mathrm{y}}-k_{a} \times \mathrm{s}
\end{aligned}
$$

The acceptability constant, $k_{a}$, is 1.40 for more than four-hundred test results (allowable probability constant $\mathrm{CR}=5 \%$ and percentile $P_{\mathrm{k}}=10 \%$ ) [13].

It is wellknown that coal fly ash is used worldwide to produce blended cement and concrete. It provides improved properties including a better durability in aggressive environments and a lower hydration heat [2,7,12]. All these characteristics are affected directly by the coal fly ash fineness [55]. In particular, the finer the fly ash, the more effective it becomes in terms of compressive strength and durability $[15,56]$. This enhancement in the mechanical properties with the fineness increase has also been found in other pozzolanic materials [57]. In addition, the transition to carbon neutrality by 2050 is both the most urgent challenge and an opportunity to build a better future for the society as a whole. The increase of production and use of blended cements made with supplementary cementitious materials, such as coal fly ash, will play a big part in achieving this goal.

The upper and lower limits for the results of residue on a $45 \mu \mathrm{m}$ mesh sieve were $\mathrm{U}=27.65$ and $\mathrm{L}=17.40$, respectively.

Results from the residue on a $63 \mu \mathrm{m}$ sieve taken on 765 spot samples picked in a period of ten years are presented in Figure $2 \mathrm{~b}$. The data show significant scatter due the above-mentioned effects. Most of the residues are ranged from $10 \%$ to $20 \%$. Regarding to the residues on a $90 \mu \mathrm{m}$ sieve, the coal fly ash samples neatly fit in the middle of the $10 \%$. Finally, only less than 5\% of the coal fly ash particulates are larger than $200 \mu \mathrm{m}$. When sieving tests are conducted on a $200 \mu \mathrm{m}$ sieve, a lower scatter of results occurred during the last four years of testing. The convergence assignment may be directed towards the smaller size tendency of the coal fly ash particulates found in the last period.

These results support the low fineness and high reactivity of the Carboneras coal fly ash reported in reference [14]. As a result, it is believed that, in this case, is not necessary to use postproduction processing of the coal fly ash to refine the particle size.

\subsection{Coal Fly Ash Fineness in the European Context}

Figure 3 illustrates the upper and lower ranges of the particle size distribution of 23 European coal fly ashes [58]. Superimposed on this plot are the maximum, average and minimum values of the Carboneras coal fly ash. The average particle size of the Carboneras coal fly ash is close to the lower bound, while the maximum values neatly fit in the middle of the upper and lower bounds. Most of the particulates are below $45 \mu \mathrm{m}$ and only a maximum of $10 \%$ are over $200 \mu \mathrm{m}$. The reason for the coal ashes containing particles having a high size is that are made up of the unburnt coal (char) or the organic constituents [59]. Also, it could be due to germination of spheres and particle grouping in liquid states or, simply, they could be of primary origin [60]. 


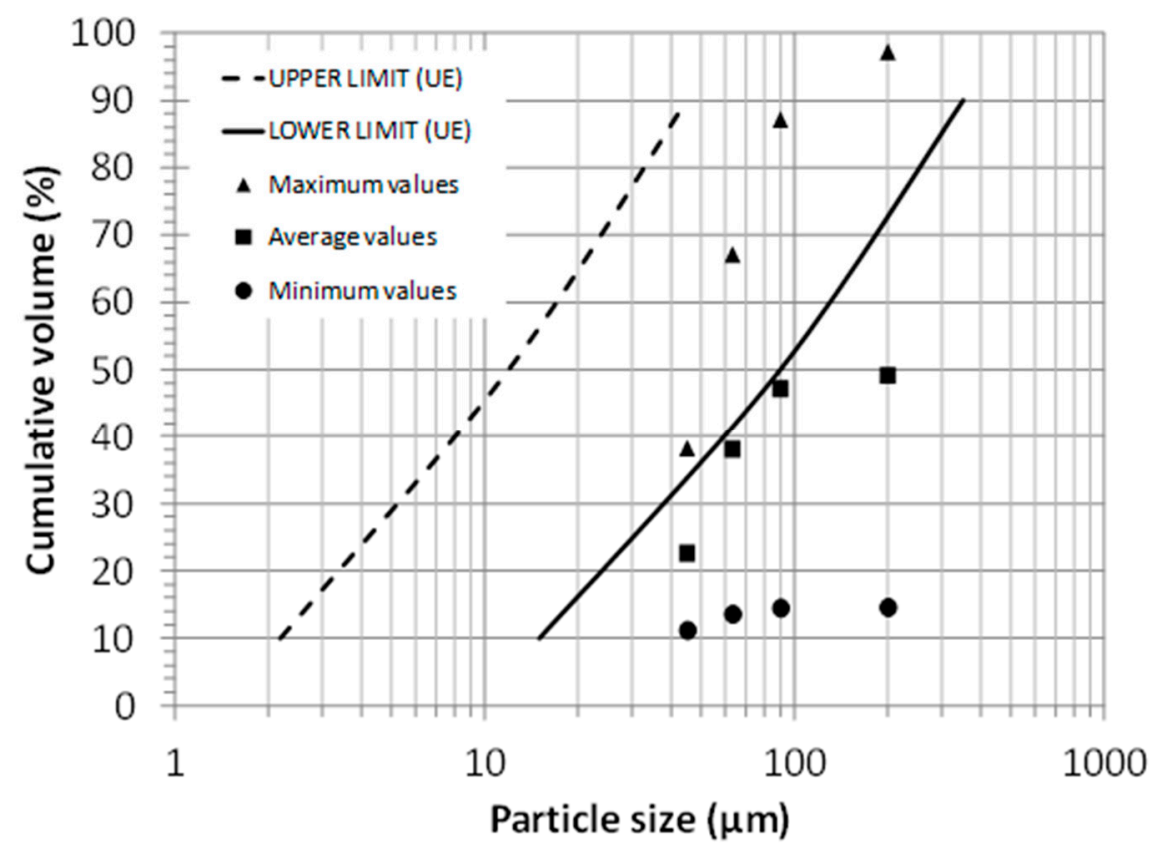

Figure 3. Maximum, average and minimum values of the Carboneras coal fly ash and the upper and lower ranges of the particle size distribution of 23 European coal fly ashes [58].

\subsection{Coal Fly Ash Fineness Statistical Approach}

Figure 4 plots a histogram that graphically summarizes the distribution of the residues on the $45 \mu \mathrm{m}, 63 \mu \mathrm{m}, 90 \mu \mathrm{m}$ and $200 \mu \mathrm{m}$ sieves, recorded from 765 spot samples picked in a period of ten years. These histograms have been obtained by splitting the range of the data into equal-sized classes of residues of $1 \%$, from $1 \%$ to $40 \%$. The four histograms show that the data are approximated well by normal distributions with a single peak at the center and well-behaved tails. Therefore, it is reasonable to use the mean value as the location estimator.

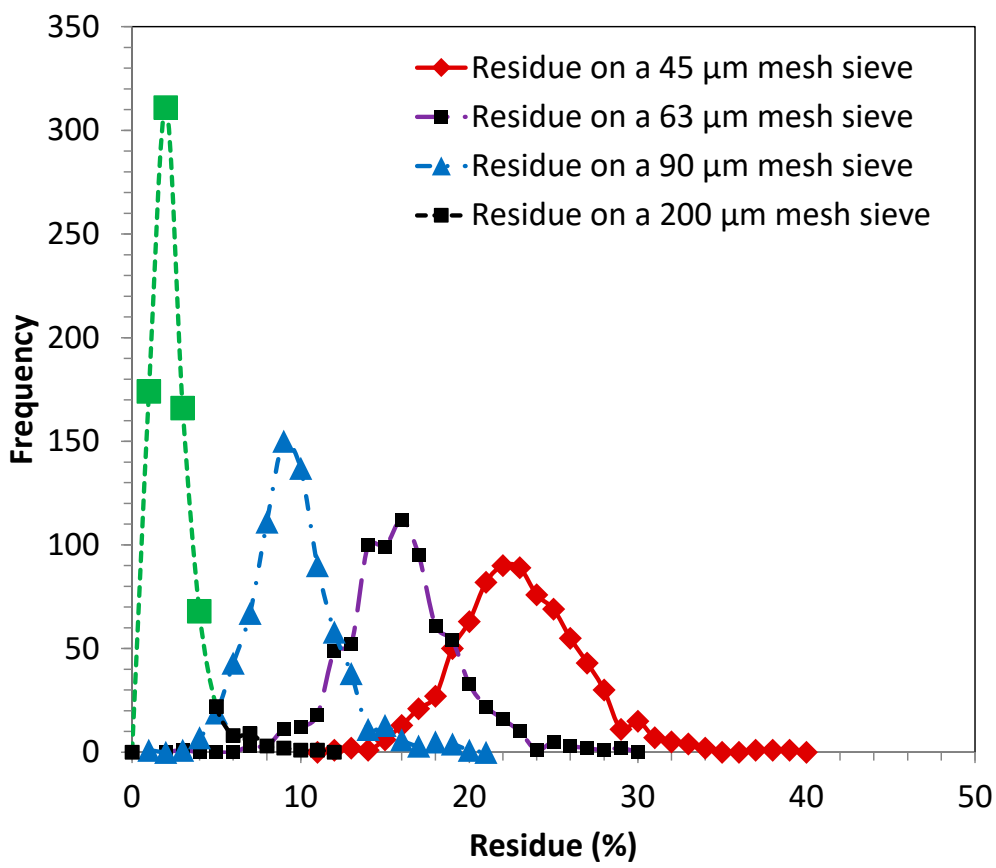

Figure 4. Frequency of the residues on the $45 \mu \mathrm{m}, 63 \mu \mathrm{m}, 90 \mu \mathrm{m}$ and $200 \mu \mathrm{m}$ sieves, recorded from 765 spot samples picked in a period of ten years. 
Maximum, average, minimum and standard deviation of the residues obtained on the $45 \mu \mathrm{m}, 63 \mu \mathrm{m}, 90 \mu \mathrm{m}$ and $200 \mu \mathrm{m}$ sieves are given in Figure 5 . The fineness on $45 \mu \mathrm{m}, 63 \mu \mathrm{m}$, $90 \mu \mathrm{m}$ and $200 \mu \mathrm{m}$ sieves, expressed as average value (and their standard deviations) were $22.5 \%(3.7 \%), 15.5 \%(3.3 \%), 9.1 \%$ (2.5\%) and 2.0\% (1.3\%), respectively. As may be seen, average results are rather low. However, at the upper bound the samples may contain up to $10 \%$ which exceeds the $200 \mu \mathrm{m}$. These coal fly ash particulates could be thoughtful as an inert constituent in concrete.

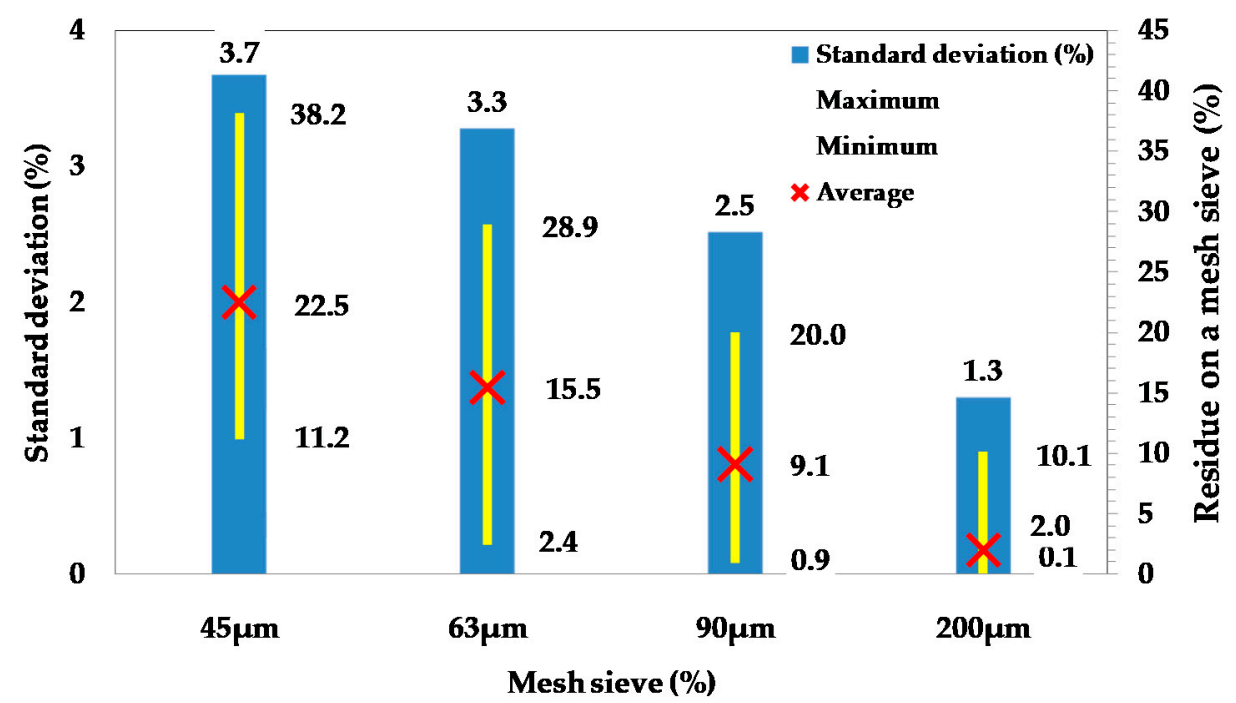

Figure 5. Maximum, average minimum and standard deviation results for the $45 \mu \mathrm{m}, 63 \mu \mathrm{m}, 90 \mu \mathrm{m}$ and $200 \mu \mathrm{m}$ sieve residues, calculated from 765 spot samples picked in a period of ten years.

The relationship between the residues on the $45 \mu \mathrm{m}$ and $63 \mu \mathrm{m}$ mesh sieves, obtained in seven hundred sixty-five coal fly ash samples collected for ten years is shown in Figure 6. A linear trend has been observed and represented with Equation (3). The slope of the regression line indicates that, on the average, one should expect an increase on the $63 \mu \mathrm{m}$ mesh sieve of about $13 \%$ for every $20 \%$ increase on the $45 \mu \mathrm{m}$ mesh sieve.

$$
\mathrm{R} 63 \mu \mathrm{m}=0.7962 \times \mathrm{R} 45 \mu \mathrm{m}-2.4536\left(\mathrm{R}^{2}=0.79\right)
$$

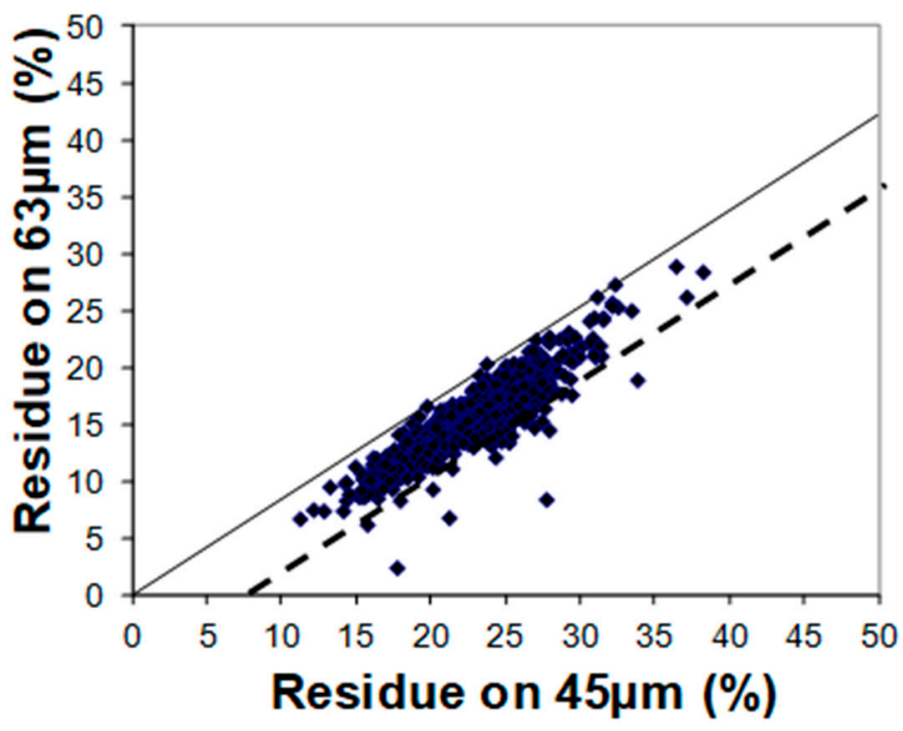

Figure 6. Relationship between the coal fly ash retained on the $45 \mu \mathrm{m}$ and $63 \mu \mathrm{m}$ sieves, calculated from 765 spot samples picked in a period of ten years. 
A similar relationship between the $45 \mu \mathrm{m}$ and $90 \mu \mathrm{m}$ sieved residues was also found as shown in Figure 7. In this case, the correlation is worse than in the previous one Equation (4).

$$
\mathrm{R} 90 \mu \mathrm{m}=0.5702 \times \mathrm{R} 45 \mu \mathrm{m}-3.7535\left(\mathrm{R}^{2}=0.69\right)
$$

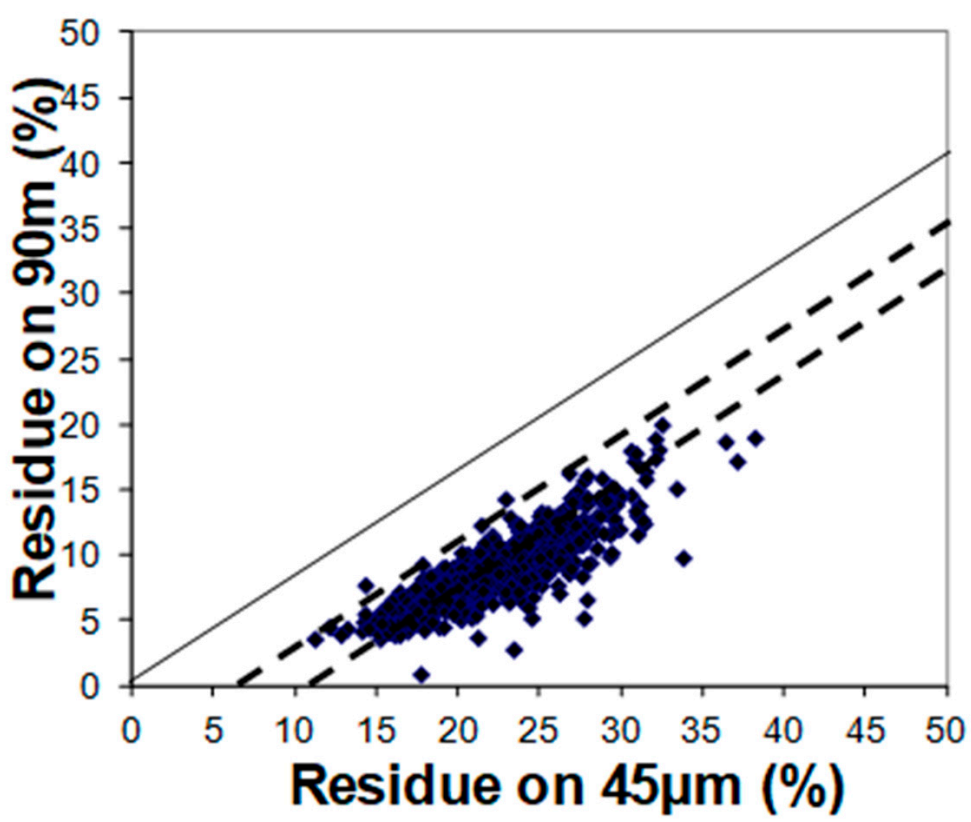

Figure 7. Relationship between the coal fly ash retained on the $45 \mu \mathrm{m}$ and $90 \mu \mathrm{m}$ mesh sieves, calculated from 765 spot samples picked in a period of ten years.

With regard to the relationship between the $45 \mu \mathrm{m}$ and $200 \mu \mathrm{m}$ sieved residues (Figure 8), it is evident that it does not follow a clear linear relationship Equation (5).

$$
\mathrm{R} 200 \mu \mathrm{m}=0.2284 \times \mathrm{R} 45 \mu \mathrm{m}-3.1772\left(\mathrm{R}^{2}=0.42\right)
$$

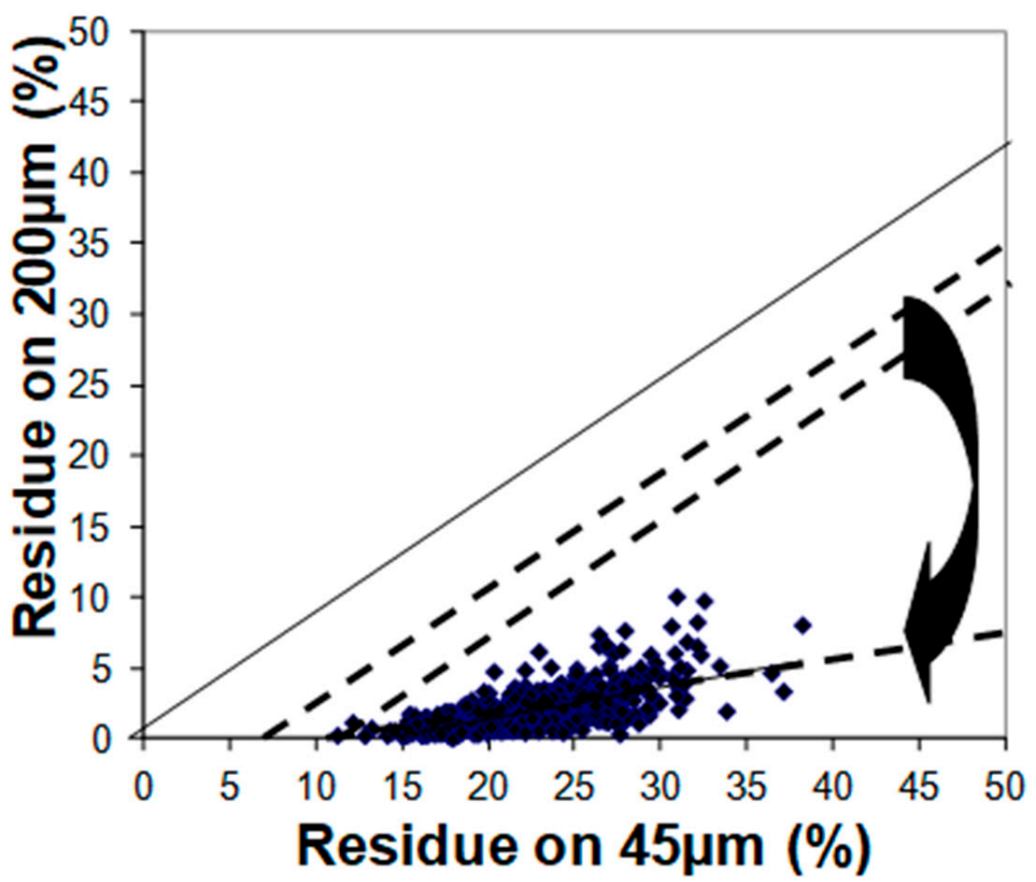

Figure 8. Relationship between the coal fly ash retained on the $45 \mu \mathrm{m}$ and $200 \mu \mathrm{m}$ mesh sieves, calculated from 765 spot samples picked in a period of ten years. 
In conclusion, it can be assumed that the percentage of coal fly ash retained on a $45 \mu \mathrm{m}$ mesh sieve is an indirect indicator of the residues on the $63 \mu \mathrm{m}, 90 \mu \mathrm{m}$ and $200 \mu \mathrm{m}$ sieves. This fact supports that this parameter can be used alone to estimate some concrete properties. Lane and Best [61] state that results of the residues on the $45 \mu \mathrm{m}$ mesh sieve can be used as a means to correlate the fineness of coal fly ash with certain concrete properties such as mechanical strength and durability (high freezing and thawing and abrasion resistance). A study on coal fly ash collected from various precipitator fields of in a single source by Ravina [62] showed that fineness can vary from $9.7 \%$ to $35 \%$ and he concludes that the fineness of coal fly ash, defined as the percentage retained on a $45 \mu \mathrm{m}$ sieve, has a good correlation with concrete compressive strength $[61,62]$. The average value $(22.5 \%)$ of the residue on the $45 \mu \mathrm{m}$ obtained in this research corresponds to an activity index with a value of $90 \%$ according to Ravina's work [62].

More recent studies [8] show that also ground coal bottom ash performs adequately with a fineness similar to that of the cement. In particular, there are direct functions of these properties with the proportion of the coal fly ash finer than the $45 \mu \mathrm{m}$. Given that, fineness of a coal fly ash has a clear influence on its performance in concrete and it may be a relatively consistent indicator of coal fly ash performance in concrete. Then, it can be said that the fineness of coal fly ash, defined by the European standard EN 450-1 [13] and by the ASTM C 618 [63] as the percentage retained on a $45 \mu \mathrm{m}$ sieve (No. 325), when tested using the method defined in the EN 451-2 (wet-sieved) [53], is a useful parameter with which to evaluate coal fly ash for use in concrete.

In consequence, coal fly ash fineness is controlled in Europe [13] and USA [63] by limiting the amount retained on the $45 \mu \mathrm{m}$ (No. 325) sieve by wet sieving. The EN 450-1 [13] limits the amount retained to 40\% (category N), whereas the ASTM C 618 [63] limits the amount retained to $34 \%$ (Classes F, C and N). Then, it is evident that this parameter is widely regarded as a significant indicator of quality. The specification requirement for fineness uniformity is also different. The maximum variation allowed is \pm 10 percentage points from average in the EN 450-1 [13] and \pm 5 percentage points from average in the ASTM C 618 [63]. Then, the specification requirement for fineness uniformity can be expressed mathematically as given in Equation (6).

$$
\mathrm{D}=\overline{\mathrm{y}}_{10}-\mathrm{x}_{\mathrm{i}}
$$

where $\mathrm{D}$ is the maximum difference between the mean of the previous ten samples $\left(\overline{\mathrm{Y}}_{10}\right)$ and the value for the sample currently under test $\left(\mathrm{x}_{\mathrm{i}}\right)$. This requirement is set at $10 \%$ by the European standard for coal fly ash requirements, EN 450-1 [13], and 5\% by the ASTM C 618 [63]. The specification requirement for fineness uniformity considering the residues on the $45 \mu \mathrm{m}$ mesh sieve from 765 spot samples picked in a period of ten years is plot in Figure 9 (dotted line-ASTM C 618 [63] and solid line-EN 450-1 [13]). The uniformity limits for fineness are $\pm 5 \%$ relative to the running 10 average in the ASTM C 618 [63].

From results in Figure 9, it can be observed that 80 samples (10.5\%) did not comply with the ASTM C 618 [63] requirement for fineness uniformity $( \pm 5 \%)$. This result confirms that this variation requirement was the most frequent cause of coal fly ash failing to meet requirements. Then, these limits are considered very strict and unrealistic. Therefore, it could be requested to broaden the range from $\pm 5 \%$ to as high as $\pm 7 \%$ or $\pm 10 \%$. On the other hand, the European uniformity limits for fineness are $\pm 10 \%$ relative to the running 10 average [13]. From results in Figure 9, it can be observed that only seven samples (0.9\%) did not comply with the current European requirement [13] for fineness uniformity ( $\pm 10 \%)$. Considering a new requirement for fineness uniformity as high as $\pm 7 \%$, only 30 samples $(3.9 \%)$ did not comply with the new proposal. Thus, it is suggested to broaden the range from $\pm 5 \%$ to as high as $\pm 7 \%$ in the ASTM C 618 [63]. Nevertheless, more data are needed to establish an appropriate range. 


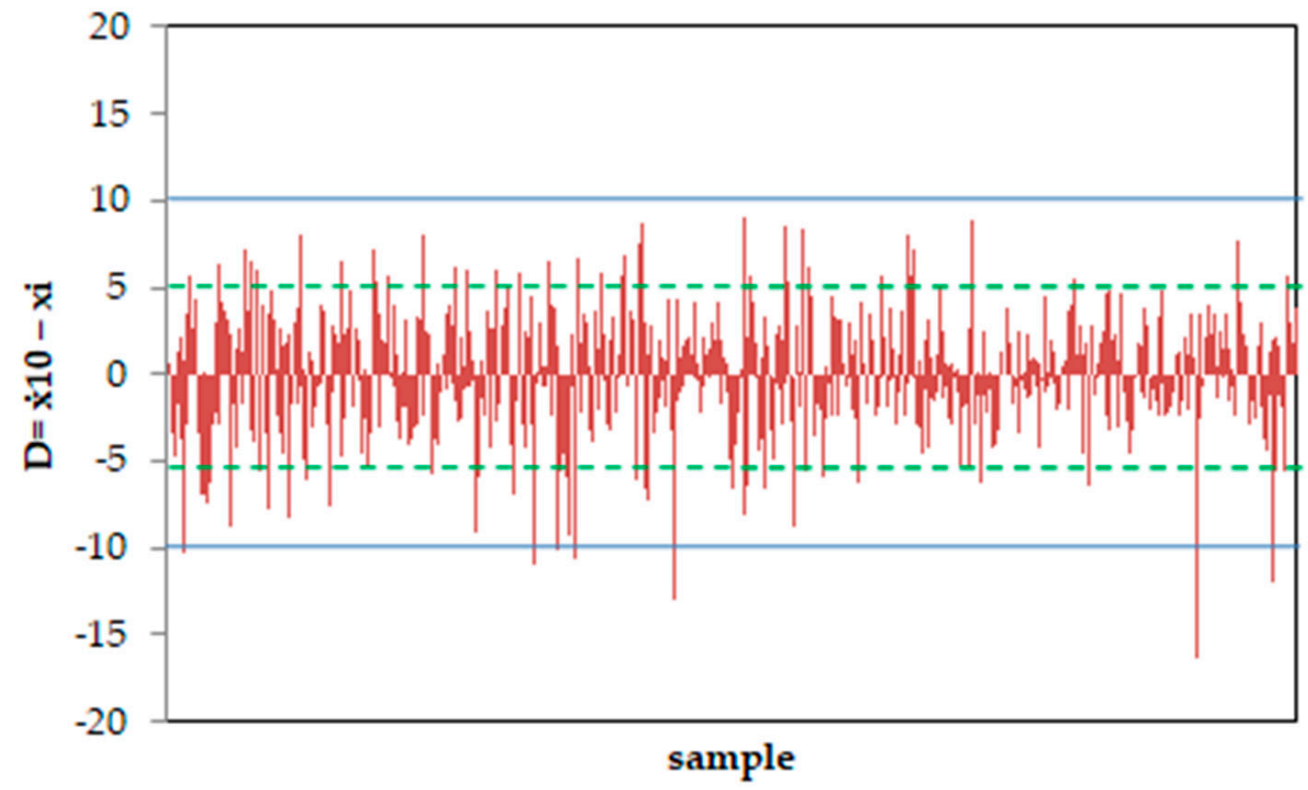

Figure 9. Fineness uniformity: European $( \pm 10 \%)$ and ASTM C $618( \pm 5 \%)$ requirements for the residues on the $45 \mu \mathrm{m}$ sieve, calculated from 765 spot samples picked in a period of ten years.

Fineness uniformity, as described by the European standard for coal fly ash requirements, EN 450-1 [13], is directly related to the within-source standard deviation among samples. In order to estimate the frequency with which D will exceed the $5 \%$ or $10 \%$ requirements, the variance in $\mathrm{D}\left(\mathrm{s}^{2} \mathrm{D}\right)$ should be determined. The variance for a given source is related to the within-source variance among samples $\left(\mathrm{s}^{2}\right)$ may be calculated by using Equation (7) for 10 samples.

$$
\mathrm{s}^{2} \mathrm{D}=\mathrm{s}^{2} / 10+\mathrm{s}^{2}=1.1 \mathrm{~s}^{2}
$$

The standard deviation, $\mathrm{s}_{\mathrm{D}}$, is then $\mathrm{s}_{\mathrm{D}}=1.05 \mathrm{~s}$. Two standard deviations will include $95 \%$ of expected values of $\mathrm{D}$, i.e., $2 \times \mathrm{s}_{\mathrm{D}}=2.10 \mathrm{~s}$. The value of within-source standard deviation that would result in D being less than or equal to 5\% (ASTM C 618 [63]) in 95\% of cases is given in Equations (8) and (9). Therefore, sources whose standard deviation among samples is greater than $2.38 \%$ are expected to exceed the ASTM C 618 [63] requirement more than $5 \%$ of the time.

$$
\begin{gathered}
2.10 \mathrm{~s}<5 \% \\
\mathrm{~s}<2.38 \%
\end{gathered}
$$

The value of within-source standard deviation that would result in D being less than or equal to 10\% (EN 450-1 [13]) in 95\% of cases is given in Equations (10) and (11). In this case, coal fly ash suppliers whose standard deviation among samples is greater than $4.76 \%$ are expected to exceed the EN 450-1 [13] requirement more than $5 \%$ of the time.

$$
\begin{gathered}
2.10 \mathrm{~s}<10 \% \\
\mathrm{~s}<4.76 \%
\end{gathered}
$$

Within source standard deviation is dependent on sampling procedure; therefore, it has to be strictly defined to avoid compliance disputes between coal fly ash producers and users. In a popular study, Felekoğlu et al. [64] argued that achieving the highest coal fly ash mortars compressive strength mainly depends on the coal fly ash fineness. However, increasing the fineness may result with higher water demand in the concrete mix due to the increase in surface area of fine coal fly ash particles. Thus, in order to get a good concrete 
mix design, it is quite relevant to use a coal fly ash with a low variability in fineness to achieve a constant workability of the concrete over time.

\section{Conclusions}

In this work coal fly ash samples from the combustion of South African coal were investigated. The coal fly ash was produced by grate furnace combustion. The specimens' fineness was measured by wet sieving through a $45 \mu \mathrm{m}$ sieve following EN 451-2. Evaluation of 765 spot samples picked in a period of ten years and their corresponding sieved fractions of different grain size led to the following conclusions:

(1) The most significant physical performance characteristic of coal fly ash in concrete is the particle size. It can be assumed that the percentage retained on a $45 \mu \mathrm{m}$ mesh sieve is an indirect indicator of the residues on the $63 \mu \mathrm{m}, 90 \mu \mathrm{m}$ and $200 \mu \mathrm{m}$ sieves. This fact supports that this parameter alone can be used to estimate some concrete properties. Summing up, this determination on a $45 \mu \mathrm{m}$ with wet sieve method is simple to use, robust and low cost giving good relationships with other fineness ranges. Also, this method is less prone to variations and does not require specialized instrument and laboratory conditions.

(2) The ASTM C 618 variation requirement is considered very strict and unrealistic. Consequently, it can constitute the most frequent cause of coal fly ash failing to meet requirements. Thus, it is suggested to broaden the range from $\pm 5 \%$ to as high as $\pm 7 \%$.

(3) The study has shown that the coal fly ash from the Carboneras power station is efficiently produced from South African coal. The coal fly ash particle sizes were 70\% less than $45 \mu \mathrm{m}$. Apparently, particle agglomerations due to electrostatic attraction did not occur in this coal fly ash. Samples with large particle sizes probably have no implications for practice. Furthermore, the particles size distribution was evenly distributed, providing a well-graded material.

Author Contributions: Conceptualization, M.Á.S. and C.A.; methodology, M.Á.S. and C.A.; software, M.Á.S.; validation, M.Á.S.; formal analysis, M.Á.S. and C.A.; investigation, M.Á.S. and C.A.; resources, M.Á.S.; data curation, M.Á.S. and C.A.; writing—original draft preparation, M.Á.S.; writing-review and editing, M.Á.S. and C.A.; visualization, M.Á.S.; supervision, M.Á.S. All authors have read and agreed to the published version of the manuscript.

Funding: This research received no external funding.

Institutional Review Board Statement: Not applicable.

Informed Consent Statement: Not applicable.

Data Availability Statement: Not applicable.

Acknowledgments: The authors wish to acknowledge the staff of Carboneras thermal Power plant for their support and for sample collection and testing.

Conflicts of Interest: The authors state that there were no conflict of interest.

\section{References}

1. Argiz, C.; Menéndez, E.; Moragues, A.; Sanjuán, M.A. Fly ash characteristics of Spanish coal-fired power plants. Afinidad 2015, 72, 269-277. Available online: http:/ / www.raco.cat/index.php/afinidad/article/viewFile/305569/395407 (accessed on 8 May 2021).

2. The International Energy Agency (IEA). Coal 2019. Analysis and Forecast to 2024, 1st ed.; IEA: Paris, France, $2019 ;$ pp. 1-165. Available online: https:/ / www.iea.org/reports/coal-2019 (accessed on 8 May 2021).

3. European Commission. The European Green Deal. Communication from the Commission to the European Parliament, the European Council, the Council, the European Economic and Social Committee and the Committee of the Regions. Brussels, Belgium. 2019. Available online: https: / / eur-lex.europa.eu/resource.html?uri=cellar:b828d165-1c22-11ea-8c1f-01aa75ed71a1 .0002.02/DOC_1\&format=PDF (accessed on 28 November 2020).

4. European Commission. The European Climate Law. Regulation (EU) 2021/1119 of the European Parliament and The Council, of 30 June 2021 Establishing the Framework for Achieving Climate Neutrality and Amending Regulations (EC) No 401/2009 and (EU) 2018/1999 ('European Climate Law'). Official Journal of the European Union. L 243/1-L 243/17. 9 July 2021. Available online: https:/ / eur-lex.europa.eu/legal-content/EN/TXT/PDF/?uri=CELEX:32021R1119\&from=EN (accessed on 8 May 2021). 
5. European Commission. A New Circular Economy Action Plan: For a Cleaner and More Competitive Europe. Communication from the Commission to the European Parliament, The Council, the European Economic and Social Committee and the Committee of the Regions. Available online: https:/ / eur-lex.europa.eu/resource.html?uri=cellar:9903b325-6388-11ea-b735-01aa75ed71a1.0 017.02/DOC_1\&format=PDF (accessed on 8 May 2021).

6. Sanjuán, M.A.; Argiz, C.; Mora, P.; Zaragoza, A. Carbon Dioxide Uptake in the Roadmap 2050 of the Spanish Cement Industry. Energies 2020, 13, 3452. [CrossRef]

7. Taylor, H.F.W. Cement Chemistry, 2nd ed.; Thomas Telford: London, UK, 1997.

8. Argiz, C.; Sanjuán, M.; Menéndez, E. Coal Bottom Ash for Portland Cement Production. Adv. Mater. Sci. Eng. 2017, 2017, 1-7. [CrossRef]

9. Lieberman, R.N.; Knop, Y.; Querol, X.; Moreno, N.; Muñoz-Quirós, C.; Mastai, Y.; Anker, Y.; Cohen, H. Environmental impact and potential use of coal fly ash and sub-economical quarry fine aggregates in concrete. J. Hazard. Mater. 2018, 344, $1043-1056$. [CrossRef]

10. European Committee for Standardization (CEN). EN 197-1:2011. Cement_Part 1: Composition, Specifications and Conformity Criteria for Common Cement; European Committee for Standardization (CEN): Brussels, Belgium, 2011.

11. Manz, O.E. Coal fly ash: A retrospective and future look. Fuel 1999, 78, 133-136. [CrossRef]

12. Costa, U.; Massazza, F. Some properties of pozzolanic cements containing fly ashes. In Proceedings of the first CANMET/ACI International Conference on the Use of Fly Ash, Silica Fume, Slag and Other Mineral by-Products in Concrete, 1st ed.; ACI SP-79; Malhotra, V.M., Ed.; American Concrete Institute (ACI): Montebello, QU, Canada, 1983; Volume 1, pp. 235-254.

13. European Committee for Standardization (CEN). EN 450-1. Fly Ash for Concrete: Definitions, Requirements and Quality Control; European Committee for Standardization (CEN): Brussels, Belgium, 2012.

14. Sanjuán, M.A.; Argiz, C.; Menéndez, E. Efecto de la adición de mezclas de ceniza volante y ceniza de fondo procedentes del carbón en la resistencia mecánica y porosidad de cementos Portland. Mater. Construcc. 2013, 63, 49-64. [CrossRef]

15. Payá, J.; Monzó, J.; Borrachero, M.; Peris-Mora, E.; Amahjour, F. Mechanical treatment of fly ashes: Part IV. Strength development of ground fly ash-cement mortars cured at different temperatures. Cem. Concr. Res. 2000, 30, 543-551. [CrossRef]

16. Wang, S.; Baxter, L.; Fonseca, F. Biomass fly ash in concrete: SEM, EDX and ESEM analysis. Fuel 2008, 87, 372-379. [CrossRef]

17. Ranjbar, N.; Kuenzel, C. Cenospheres: A review. Fuel 2017, 207, 1-12. [CrossRef]

18. Żyrkowski, M.; Neto, R.C.; Santos, L.F.; Witkowski, K. Characterization of fly-ash cenospheres from coal-fired power plant unit. Fuel 2016, 174, 49-53. [CrossRef]

19. Sokol, E.; Maksimova, N.; Volkova, N.; Nigmatulina, E.; Frenkel, A. Hollow silicate microspheres from fly ashes of the Chelyabinsk brown coals (South Urals, Russia). Fuel Process. Technol. 2000, 67, 35-52. [CrossRef]

20. Fomenko, E.; Anshits, N.; Solovyov, L.; Mikhaylova, O.A.; Anshits, A. Composition and Morphology of Fly Ash Cenospheres Produced from the Combustion of Kuznetsk Coal. Energy Fuels 2013, 27, 5440-5448. [CrossRef]

21. Malhotra, V. Durability of concrete incorporating high-volume of low-calcium (ASTM Class F) fly ash. Cem. Concr. Compos. 1990, 12, 271-277. [CrossRef]

22. Yang, E.H.; Yang, Y.Z.; Victor Li, C. Use of High Volumes of Fly Ash to Improve ECC Mechanical Properties and Material Greenness. ACI Mater. J. 2007, 104, 303-310. [CrossRef]

23. Park, J.-H.; Bui, Q.-T.; Jung, S.-H.; Yang, I.-H. Selected Strength Properties of Coal Bottom Ash (CBA) Concrete Containing Fly Ash under Different Curing and Drying Conditions. Materials 2021, 14, 5381. [CrossRef]

24. Lam, L.; Wong, Y.; Poon, C.S. Degree of hydration and gel/space ratio of high-volume fly ash/cement systems. Cem. Concr. Res. 2000, 30, 747-756. [CrossRef]

25. Narmluk, M.; Nawa, T. Effect of fly ash on the kinetics of Portland cement hydration at different curing temperatures. Cem. Concr. Res. 2011, 41, 579-589. [CrossRef]

26. Ramezanianpour, A.; Malhotra, V. Effect of curing on the compressive strength, resistance to chloride-ion penetration and porosity of concretes incorporating slag, fly ash or silica fume. Cem. Concr. Compos. 1995, 17, 125-133. [CrossRef]

27. Hashmi, A.F.; Shariq, M.; Baqi, A. Experimental and analytical investigation on the age-dependent tensile strength of low-calcium fly ash-based concrete. Innov. Infrastruct. Solut. 2021, 6, 1-16. [CrossRef]

28. Rivera, R.A.; Sanjuán, M.Á.; Martín, D.A. Granulated Blast-Furnace Slag and Coal Fly Ash Ternary Portland Cements Optimization. Sustainability 2020, 12, 5783. [CrossRef]

29. Atis, C. High-Volume Fly Ash Concrete with High Strength and Low Drying Shrinkage. J. Mater. Civ. Eng. 2003, 15, 153-156. [CrossRef]

30. Hashmi, A.F.; Shariq, M.; Baqi, A. An investigation into age-dependent strength, elastic modulus and deflection of low calcium fly ash concrete for sustainable construction. Constr. Build. Mater. 2021, 283, 122772. [CrossRef]

31. Ankur, N.; Singh, N. Performance of cement mortars and concretes containing coal bottom ash: A comprehensive review. Renew. Sustain. Energy Rev. 2021, 149, 111361. [CrossRef]

32. Poon, C.; Lam, L.; Wong, Y. A study on high strength concrete prepared with large volumes of low calcium fly ash. Cem. Concr. Res. 2000, 30, 447-455. [CrossRef]

33. Thomas, M.D.A.; Matthews, J.D. Performance of PFA concrete in a marine environment-10-year results. Cem. Concr. Compos. 2004, 26, 5-20. [CrossRef] 
34. Nath, P.; Sarker, P.; Biswas, W. Effect of fly ash on the service life, carbon footprint and embodied energy of high strength concrete in the marine environment. Energy Build. 2018, 158, 1694-1702. [CrossRef]

35. Wang, X.-Y.; Park, K.-B. Analysis of compressive strength development of concrete containing high volume fly ash. Constr. Build. Mater. 2015, 98, 810-819. [CrossRef]

36. Shen, D.; Shi, X.; Zhu, S.; Duan, X.; Zhang, J. Relationship between tensile Young's modulus and strength of fly ash high strength concrete at early age. Constr. Build. Mater. 2016, 123, 317-326. [CrossRef]

37. Vázquez-Rivera, N.I.; Soto-Pérez, L.; John, J.N.S.; Molina-Bas, O.I.; Hwang, S.S. Optimization of pervious concrete containing fly ash and iron oxide nanoparticles and its application for phosphorus removal. Constr. Build. Mater. 2015, 93, 22-28. [CrossRef]

38. Sata, V.; Ngohpok, C.; Chindaprasirt, P. Properties of pervious concrete containing high-calcium fly ash. Comput. Concr. 2016, 17, 337-351. [CrossRef]

39. Zaetang, Y.; Wongsa, A.; Sata, V.; Chindaprasrit, P. Influence of mineral additives on the properties of pervious concrete. IJEMS 2017, 24, 507-515.

40. Saboo, N.; Shivhare, S.; Kori, K.K.; Chandrappa, A.K. Effect of fly ash and metakaolin on pervious concrete properties. Constr. Build. Mater. 2019, 223, 322-328. [CrossRef]

41. Mardani-Aghabaglou, A.; Ramyar, K. Mechanical properties of high-volume fly ash roller compacted concrete designed by maximum density method. Constr. Build. Mater. 2013, 38, 356-364. [CrossRef]

42. Bayqra, S.H.; Mardani-Aghabaglou, A.; Ramyar, K. Physical and mechanical properties of high volume fly ash roller compacted concrete pavement (A laboratory and case study). Constr. Build. Mater. 2021, 314, 125664. [CrossRef]

43. Aguiar, L.B.; Camelo, A.M.R.O.; Ribeiro, A.C.B.S. Roller Compacted Concrete (RCC)—Strength and Permeability of Horizontal Joints. In Proceedings of the International Conference on Challenges of Concrete Construction: Volume 5, Sustainable Concrete Construction, University of Dundee, Scotland, UK, 9-11 September 2002; Dhir, R.K., Dyer, T.D., Halliday, J.E., Eds.; ICE Publishing: London, UK, 2002; pp. 751-760. [CrossRef]

44. Qian, P.; Xu, Q. Experimental investigation on properties of interface between concrete layers. Constr. Build. Mater. 2018, 174, 120-129. [CrossRef]

45. Şahmaran, M.; Keskin, S.B.; Ozerkan, G.; Yaman, I.O. Self-healing of mechanically-loaded self consolidating concretes with high volumes of fly ash. Cem. Concr. Compos. 2008, 30, 872-879. [CrossRef]

46. Jing, R.; Liu, Y.; Yan, P. Uncovering the effect of fly ash cenospheres on the macroscopic properties and microstructure of ultra high-performance concrete (UHPC). Constr. Build. Mater. 2021, 286, 122977. [CrossRef]

47. Ferdosian, I.; Camões, A.; Ribeiro, M. High-volume fly ash paste for developing ultra-high performance concrete (UHPC). Cienc. Tecnol. Mater. 2017, 29, e157-e161. [CrossRef]

48. Chindaprasirt, P.; Jaturapitakkul, C.; Sinsiri, T. Effect of fly ash fineness on compressive strength and pore size of blended cement paste. Cem. Concr. Compos. 2005, 27, 425-428. [CrossRef]

49. Wang, D.; Shi, C.; Wu, Z.; Xiao, J.; Huang, Z.; Fang, Z. A review on ultra high performance concrete: Part II. Hydration, microstructure and properties. Constr. Build. Mater. 2015, 96, 368-377. [CrossRef]

50. IPCC. 2021: Climate Change 2021: The Physical Science Basis. In Contribution of Working Group I to the Sixth Assessment Report of the Intergovernmental Panel on Climate Change; Masson-Delmotte, V., Zhai, P., Pirani, A., Connors, S.L., Péan, C., Berger, S., Caud, N., Chen, Y., Goldfarb, L., Gomis, M.I., et al., Eds.; Cambridge University Press: Cambridge, UK, 2021; Available online: https://www.ipcc.ch/report/ar6/wg1/downloads/report/IPCC_AR6_WGI_Full_Report.pdf (accessed on 8 May 2021).

51. Sanjuán, M.; Andrade, C.; Mora, P.; Zaragoza, A. Carbon Dioxide Uptake by Cement-Based Materials: A Spanish Case Study. Appl. Sci. 2020, 10, 339. [CrossRef]

52. Yu, J.; Lu, C.; Leung, C.K.; Li, G. Mechanical properties of green structural concrete with ultrahigh-volume fly ash. Constr. Build. Mater. 2017, 147, 510-518. [CrossRef]

53. European Committee for Standardization (CEN). EN 451-2. Method of Testing Fly Ash-Part 2: Determination of Fineness by Wet Sieving; European Committee for Standardization (CEN): Brussels, Belgium, 1994.

54. European Committee for Standardization (CEN). EN 196-2. Method of Testing Cement_Part 2: Chemical Analysis of Cement; European Committee for Standardization (CEN): Brussels, Belgium, 2013.

55. Dhir, R.K.; Hubbard, F.H.; Munday, J.G.L.; Jones, M.R. Characteristics of low-lime fly ashes significant to their use in concrete. In Proceedings of the 2nd International Conference on Fly Ash, Silica Fume, Slag, and Natural Pozzolans in Concrete, ACI Special Publication SP-91, Madrid, Spain; Malhotra, V.M., Ed.; The American Concrete Institute: Farmington Hills, MI, USA, 1986; pp. 693-722.

56. Aydın, S.; Karatay, Ç.; Baradan, B. The effect of grinding process on mechanical properties and alkali-silica reaction resistance of fly ash incorporated cement mortars. Powder Technol. 2010, 197, 68-72. [CrossRef]

57. Sanjuán, M.; Argiz, C.; Galvez, J.; Moragues, A. Effect of silica fume fineness on the improvement of Portland cement strength performance. Constr. Build. Mater. 2015, 96, 55-64. [CrossRef]

58. Moreno, N.; Querol, X.; Andrés, J.M.; Stanton, K.; Towler, M.; Nugteren, H.; Janssen-Jurkovicová, M.; Jones, R. Physico-chemical characteristics of European pulverized coal combustion fly ashes. Fuel 2005, 84, 1351-1363. [CrossRef]

59. Rubio, B.; Izquierdo, M.; Mayoral, M.; Bona, M.; Martínez-Tarazona, R. Preparation and characterization of carbon-enriched coal fly ash. J. Environ. Manag. 2008, 88, 1562-1570. [CrossRef]

60. Vassilev, S.V.; Vassileva, C.G. Mineralogy of combustion wastes from coal-fired power stations. Fuel Process. Technol. 1996, 47, 261-280. [CrossRef] 
61. Lane, R.O.; Best, J.F. Properties and Use of Fly Ash in Portland Cement Concrete. Concr. Int. Des. Constr. 1982, 4, 81-92. Available online: https://www.concrete.org/publications/internationalconcreteabstractsportal.aspx?m=details\&i=9058 (accessed on 16 May 2021).

62. Ravina, D. Optimized determination of PFA (fly ash) fineness with reference to pozzolanic activity. Cem. Concr. Res. 1980, 10, 573-580. [CrossRef]

63. American Society for Testing and Materials (ASTM). ASTM C 618-17-Standard Specification for Coal Fly Ash and Raw or Calcined Natural Pozzolan for Use in Concrete; American Society for Testing and Materials (ASTM): Philadelphia, PA, USA, 2017.

64. Felekoğlu, B.; Türkel, S.; Kalyoncu, H. Optimization of fineness to maximize the strength activity of high-calcium ground fly ash-Portland cement composites. Constr. Build. Mater. 2009, 23, 2053-2061. [CrossRef] 